\title{
Pengaruh Financial Leverage Dan Operating Leverage Terhadap Rentabilitas PT Kalbe Farma, Tbk
}

\author{
Novia Sibarani ${ }^{1,{ }^{*}}$, Eri Bukhari ${ }^{1}$ \\ ${ }^{1}$ Manajemen, Fakultas Ekonomi, Universitas Bhayangkara Jakarta Raya; Jl. Raya \\ Perjuangan, Marga Mulya, Bekasi Utara, Jawa Barat 17121. Telp: 021-88955882, 889955883, \\ e-mail: sibaraninovia@gmail.com, eri_bukhari@yahoo.com \\ * Korespondensi: e-mail: eri_bukhari@yahoo.com
}

\begin{abstract}
This study aims to determine the effect of Financial Leverage and Operating Leverage partially and simultaneously on the Profitability of PT. Kalbe Farma, Tbk. The data used is the Financial Report for the period 2002 to 2018. The data analysis technique used is Multiple Linear Regression Analysis. Based on the results of the analysis show that partially Financial Leverage does not significantly influence Rentability, while the Operating Leverage partially has a significant effect on Rentability. Simultaneously Financial Leverage and Operating Leverage have a significant effect on Rentability.
\end{abstract}

Keywords: financial leverage, operating leverage, return on equity, profitability

\begin{abstract}
Abstrak
Penelitian ini bertujuan untuk mengetahui pengaruh Financial Leverage dan Operating Leverage secara parsial dan secara simultan terhadap Rentabilitas PT. Kalbe Farma, Tbk. Adapun data yang digunakan adalah Laporan Keuangan periode tahun 2002 sampai dengan tahun 2018. Teknik analisis data yang digunakan adalah Analisis Regresi Linear Berganda. Berdasarkan Hasil analisis menunjukan bahwasecara parsial Financial Leverage tidak berpengaruh signifikan terhadap Rentabilitas, sedangkan Operating Leverage secara parsial berpengaruh signifikan terhadap Rentabilitas. Secara simultan Financial Leverage dan Operating Leverage berpengaruh signifikan terhadap Rentabilitas.
\end{abstract}

Kata Kunci: financial leverage, operating leverage, return on equity, rentabilitas

\section{Pendahuluan}

Seiring dengan perkembangan zaman dan meningkatnya persaingan bisnis, menuntut setiap perusahaan untuk mampu menyesuaikan keadaan yang sedang terjadi dan dapat mengelola bisnisnya sedemikian rupa agar memiliki keunggulan yang kompetitif dari para pesaing. Setiap Perusahaan dalam menjalankan bisnisnya memiliki tujuan utama yaitu untuk memperoleh laba seoptimal mungkin dengan memperhatikan seluruh dana yang dioperasikan. Oleh karena itu manajemen perusahaan dalam praktiknya dituntut harus mampu untuk memenuhi target yang telah ditetapkan, artinya besarnya keuntungan haruslah dicapai sesuai dengan yang diharapkan. 
Sumber modal terbagi menjadi sumber modal internal maupun eksternal. Modal yang dihasilkan dari internal perusahaan berupa laba ditahan (retained earnings) dan akumulasi penyusutan (depreciations), sedangkan sumber eksternal yaitu sumber dana yang berasal dari luar perusahaan yang diperoleh dari kreditur dan para pemegang saham. Modal dari kreditur disebut sebagai modal asing. Dana eksternal yang dibutuhkan perusahaan berupa leverage.

Dalam Manajemen keuangan perusahaan, terdapat dua jenis leverage yaitu Financial Leverage dan Operating Leverage. Leverage adalah penggunaan aktiva dan sumber dana yang berasal dari pinjaman karena memiliki bunga sebagai beban tetap dengan maksud agar meningkatkan keuntungan potensi pemegang saham. Selain itu apabila perusahaan mendapatkan keuntungan lebih rendah dari biaya tetapnya maka penggunaan leverage akan menurunkan keuntungan pemegang saham.

Financial Leverage adalah kemampuan perusahaan dalam menggunakan kewajiban finansial tetapnya untuk menaikan tingkat Laba sebelum Bunga dan Pajak terhadap pendapatan perlembar saham biasa (earning per share/eps). Sedangkan Operating Leverage terjadi pada saat perusahaan mempergunakan aktiva tetap dalam operasi perusahaan. Operating Leverage menunjukan seberapa besar biaya tetap digunakan dalam operasi perusahaan untuk memperbesar pengaruh dari perubahan volume penjualan terhadap Laba sebelum Bunga dan Pajak. diharapkan perubahan penjualan akan mengakibatkan perubahan Laba sebelum Pajak yang lebih besar melalui penggunaan Operating Leverage.

Rentabilitas adalah kemampuan perusahaan dalam menghasilkan laba dengan semua modal yang bekerja didalamnya. Pengukuran Rentabilitas bertujuan untuk mengukur tingkat efektifitas manajemen dalam menjalankan operasional perusahaan.

Dalam penelitian ini rasio yang digunakan sebagai alat ukur Rentabilitas adalah Return On Equity. Rasio ini penting bagi pemegang saham untuk mengetahui efektifitas dan efisiensi pengelolaan modal sendiri yang dilakukan oleh pihak manajemen perusahaan.

PT Kalbe Farma, Tbk merupakan salah satu sektor Perusahaan farmasi yang terdaftar di Bursa Efek Indonesia. Perusahaan sektor farmasi pada umumnya sangat berkaitan dengan ketersediaan obat-obatan yang dibutuhkan oleh masyarakat, oleh karena itu untuk meningkatkan operasionalisasi usahanya, salah satu yang dilakukan adalah dengan melakukan penambahan dana,Maka PT. Kalbe Farma, Tbk perlu memperhatikan pentingnya Financial Leverage dan Operating Leverage karena hal ini menunjukan bagaimana kemampuan perusahaan mengelola modal yang maksimal. Berikut ini tabelkondisi keuangan PT. Kalbe Farma, Tbk tahun 2002-2018. 
Tabel 1. Laba dan Ekuitas PT. Kalbe Farma, Tbk

\begin{tabular}{|c|c|c|c|}
\hline Tahun & $\begin{array}{c}\text { Laba Setelah } \\
\text { Pajak }\end{array}$ & Ekuitas & $\begin{array}{l}\text { ROE } \\
(\%)\end{array}$ \\
\hline 2002 & 266.933.358.365 & 489.918 .226 .544 & 54 \\
\hline 2003 & 322.884 .550 .887 & 828.957 .856 .341 & 39 \\
\hline 2004 & 372.335 .218 .425 & 1.219.193.365.029 & 31 \\
\hline 2005 & 653.329.399.498 & 2.333 .172 .156 .611 & 28 \\
\hline 2006 & 676.581 .653 .872 & 2.994.816.751.748 & 23 \\
\hline 2007 & 705.694 .196 .679 & 3.386.861.941.228 & 21 \\
\hline 2008 & 706.822 .146 .190 & 3.622.399.153.499 & 20 \\
\hline 2009 & 929.003 .740 .338 & 4.310.437.877.062 & 22 \\
\hline 2010 & 1.286 .330 .026 .012 & 5.373.784.301.200 & 24 \\
\hline 2011 & 1.522 .956 .820 .292 & 6.515 .935 .058 .426 & 23 \\
\hline 2012 & 1.775 .098 .847 .932 & 7.371.643.614.897 & 24 \\
\hline 2013 & 1.970 .452 .449 .686 & 8.499.957.965.575 & 23 \\
\hline 2014 & 2.122.677.647.816 & 9.817 .475 .678 .446 & 22 \\
\hline 2015 & 2.057.694.281.873 & 10.938.285.985.269 & 19 \\
\hline 2016 & 2.350 .884 .933 .551 & 12.463 .847 .141 .085 & 19 \\
\hline 2017 & 2.453.251.410.804 & 13.894.031.782.689 & 18 \\
\hline 2018 & 2.497.261.964.757 & 15.294 .594 .796 .354 & 16 \\
\hline \multicolumn{3}{|c|}{ Rata-rata } & 25 \\
\hline
\end{tabular}

Sumber: Laporan Keuangan PT. Kalbe Farma, Tbk

Berdasarkan Tabel 1. Laba dan Ekuitas PT Kalbe Farma, Tbk mengalami peningkatan, namun pada tahun 2015 terjadi penurunan Laba, sedangkan ditahun tersebut penggunaan Ekuitas mengalami kenaikan. Dalam penelitian ini rasio yang digunakan sebagai alat ukur Rentabilitas adalah Return On Equity. 
Submitted: 9 Nopember 2019; Revised: 23 Nopember 2019; Accepted: 7 Desember 2019; Published: 25 Januari 2020

Rasio Return On Equity penting bagi pemegang saham untuk mengetahui efektifitas dan efisiensi pengelolaan modal sendiri yang dilakukan oleh pihak manajemen perusahaan.

Semakin tinggi tingkat Return On Equity berarti semakin efisien penggunaan modal Perusahaan, Karena menunjukan bagaimana kemampuan perusahaan dalam mengelola modal untuk menghasilkan Rentabilitas yang maksimal. Berikut ini grafik yang menunjukan perubahan Return On Equity pada PT Kalbe Farma, Tbk Periode 2002 - 2018.

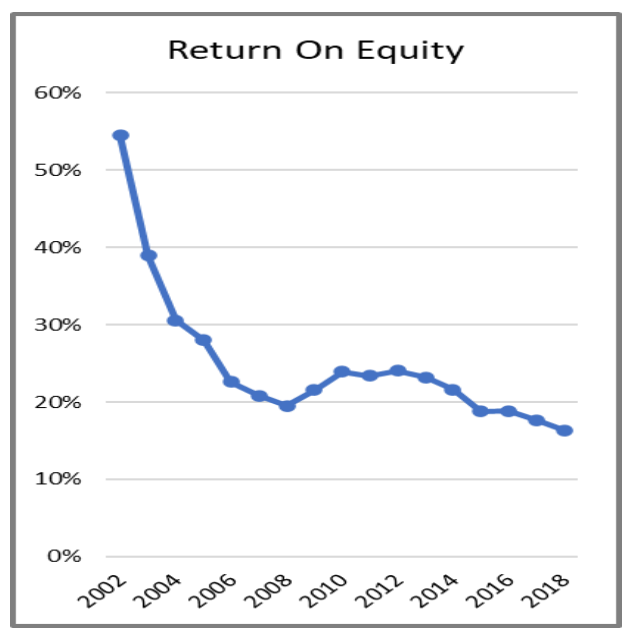

Sumber: Data Diolah, 2019

Gambar 1. Grafik Return On Equity PT Kalbe Farma, Tbk

Selama Tahun 2002 hingga tahun 2018 Return On Equity PT. Kalbe Farma, Tbk mengalami penurunan meskipun terjadi peningkatan pada Laba dan Total Ekuitas. Hal ini merupakan suatu masalah yang harus segera diatasi karena tingkat Return On Equity yang rendah akan memberikan dampak pada kepercayaan penanam modal ataupun kreditur yang akan menyimpan dananya. Oleh karena itu harus dapat dianalisis faktor-faktor yang berpengaruh terhadap Return On Equity Perusahaan.

Leverage merupakan salah satu faktor yang mendapat perhatian dari pihak eksternal maupun internal perusahaan, karena Leverage menunjukan kemampuan perusahaan dalam mengelola modal dalam bentuk utang untuk dapat menghasilkan Laba yang maksimal. Berdasarkan latar belakang diatas, maka penulis tertarik untuk melakukan penelitian dengan judul "Pengaruh Financial Leverage dan Operating Leverage Terhadap Rentabilitas PT. Kalbe Farma, Tbk".

\section{A. Rentabilitas}

Penggunaan Leverage, merupakan suatu usaha Perusahaan untuk meningkatkan Rentabilitas. Rentabilitas adalah kemampuan perusahaan dalam menghasilkan laba yang bertujuan untuk mengukur tingkat efektifitas manajemen dalam menjalankan operasional perusahaannya. Maka dapat dikatakan semakin tinggi rasio rentabilitas, maka menggambarkan semakin baik kemampuan tingginya perolehan keuntungan perusahaan. 
Rentabilitas yang digunakan adalah ROE (Return On Equity) sebagai alat ukur seberapa besar jumlah laba bersih yang dihasilkan dari setiap dana dalam total ekuitas. Menurut Mia Lasmi (2017) Return On Equity (ROE) adalah rasio untuk mengukur kemampuan modal dalam menghasilkan pendapatan bersih.

Dapat disimpulkan Return On Equity (ROE) adalah salah satu acara yang dapat digunakan untuk menghitung efisiensi perusahaan yang dilakukan dengan cara membandingkan laba bersih setelah pajak dengan jumlah modal sendiri yang menghasilkan laba tersebut.

Perhitungan rasio ini berfungsi untuk mengetahui berapa rupiah dari modal sendiri yang dijadikan untuk jaminan hutang. Besar-Kecilnya hutang perusahaan akan mempengaruhi hasil ROE dalam perhitungan Return On Equity (ROE). Rumus untuk menghitung Return On Equity adalah sebagai berikut:

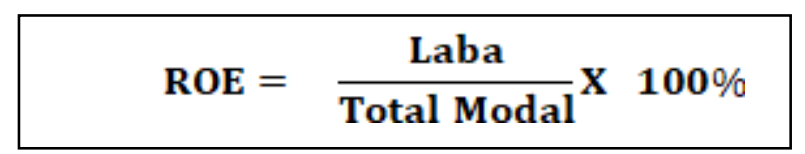

\section{B. Leverage}

Leverage merupakan hasil dari penggunaan dana dengan biaya tetap untuk meningkatkan pengembalian kepada pemegang saham. Menurut Warsono (2003) dalam Ashari dan Sampurno (2017) menyebutkan leverage adalah setiap penggunaan asset dan dana yang membawa konsekuensi biaya dan beban tetap.

Tapi disisi lain, Leverage juga dapat meningkatkan resiko jika keadaan perusahaan sedang merugi atau sedang mengalami penurunan laba, karena harus membayar beban bunga yang besar (Lestari \& Nuzula, 2017).

Istilah Leverage pada umumnya dipergunakan untuk menggambarkan kemampuan suatu perusahaan dalam mengunakan aktiva atau dana yang mempunyai beban tetap untuk memperbesar tingkat penghasilan (return) bagi pemilik perusahaan.

Analisis Leverage terbagi menjadi 2 (dua) kategori, yaitu: Financial Leverage dan Operating Leverage.

\section{1). Financial Leverage}

Financial Leverage adalah penggunaan modal pinjaman disamping modal sendiri, untuk itu perusahaan harus membayar beban tetap berupa beban bunga. Oleh sebab itu perusahaan harus tetap membayar beban bunga terlepas apakah perusahaan memperoleh laba ataupun merugi (Rodoni \& Ali, 2014).

Tujuan utama Perusahaan menggunakan Financial Leverage adalah untuk memperbesar pengembalian pemegang saham. Untuk mengukur Financial Leverage digunakan Degree Of Financial Leverage yang dirumuskan sebagai berikut:

$$
\mathrm{DFL}=\frac{\text { Persentase Perubahan EPS }}{\text { Persentase Perubahan EBIT }}
$$




\section{2). Operating Leverage}

Operating Leveragemerupakan penggunaan aktiva, dimana dalam penggunaan tersebut perusahaan harus menutupi biaya tetap (Rodoni \& Ali, 2014).

Dengan menggunakan Operating Leverage, perusahaan mengharapkan perubahan penjualan yang akan mengakibatkan perubaha laba sebelum bunga dan pajak yang lebih besar.

Menurut (Patel \& Bodiwala, 2014) bahwa dalam mengukur Operating Leverage digunakan Degree Of Operating Leverage (DOL). Dari DOL dapat dilihat hubungan antara penjualan dengan EBIT.Maka DOL menunjukan persentase perubahan profit yang diperoleh dari hasil operasi perusahaan dihubungkan dengan besarnya persentase perubahan volume penjualan.

Perusahaan yang menggunakan biaya tetap yang tinggi dikatakan bahwa perusahaan tersebut menggunakan Operating Leverage yang tinggi, artinya tingkat penjualan yang dihasilkan juga harus meningkat, karena jika tingkat penjualan menurun secara signifikan maka perusahaan tersebut akan mengalami kerugian.

Melalui analisis Operating Leverage diukur dengan DOL dapat dirumuskan sebagai berikut:

$$
\text { DOL }=\frac{\text { Persentase Perubahan EBIT }}{\text { Persentase Perubahan Penjualan }}
$$

\section{Kerangka Pemikiran}

Kerangka berpikir dalam penelitian ini dapat digambarkan sebagai berikut:

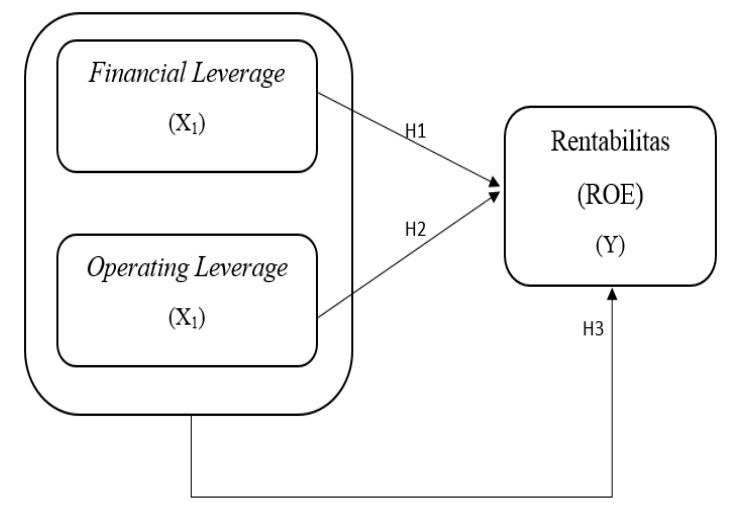

Sumber: Data Diolah, 2019

Gambar 2. Grafik Return On Equity PT Kalbe Farma, Tbk

\section{Hipotesis Penelitian}

Hipotesis merupakan salah satu tahap dalam proses pengambilan keputusan, dalam tahap ini hipotesis sebagai jawaban sementara yang kebenarannya masih harus diuji.

Mengacu pada latar belakang dan berdasarkan pada landasan teori serta kerangka penelitian, maka dapat ditarik hipotesis sebagai berikut: 
$\mathrm{H}_{1}$ : Financial Leverage berpengaruh signifikan terhadap Rentabilitas PT Kalbe Farma, Tbk

$\mathrm{H}_{2} \quad$ : Operating Leverage berpengaruh signifikan terhadap Rentabilitas PT Kalbe Farma, Tbk

$\mathrm{H}_{3}$ : Financial Leverage dan Operating Leverage secara Simultan berpengaruh signifikan terhadap Rentabilitas PT Kalbe Farma, Tbk

\section{Metode Penelitian}

\section{A. Desain Penelitian}

Pendekatan yang digunakan dalam penelitian ini adalah pendekatan kuantitatif. Metode penelitian kuantitatif berfungsi sebagai sesuatu yang akan diuji kebenarannya melalui hasil penelitian. Jenis penelitian yang dilakukan adalah penelitian eksplanatori (explanatory research). Melalui penelitian ini akan dijelaskan apakah variabel bebas Financial Leverage dan Operating Leverage akan mempengaruhi Rentabilitas sebagai variabel terikat atau tidak berpengaruh.

B. Waktu dan empat Penelitian

Penelitian dilakukan pada PT. Kalbe Farma, Tbk yang terdaftar di Bursa Efek Indonesia periode 2002-2018, data diperoleh melalui situs www.idx.co.id dan juga melalui website PT Kalbe Farma, Tbk yaitu www.kalbe.co.id dengan waktu periode penelitian selama 3 (tiga) bulan.

\section{Metode Pengambilan Sampel}

Populasi dalam penelitian ini adalah PT. Kalbe Farma, Tbk. Sedangkan sampel yang digunakan untuk penelitian ini adalah Laporan Keuangan Tahunan PT. Kalbe Farma, Tbk Periode 2002 hingga tahun 2018.

\section{Analisis Data}

Analisis data diartikan sebagai upaya data yang sudah tersedia kemudian diolah uji statistik dengan tujuan untuk menjawab rumusan masalah (Sujarweni, 2015).

\section{1) Uji Asumsi Klasik}

Uji asumsi klasik yang digunakan dalam penelitian ini bertujuan untuk menguji data yang digunakan dalam penelitian ini apakah telah memenuhi uji asumsi klasik yaitu: data berdistribusi normal, tidak terjadi gejala multikolinearitas, tidak terjadi gejala heterokedastisitas dan tidak terdapat autokorelasi. Jika telah memenuhi keempat hal tersebut maka model regresi akan memberikan hasil penaksiran yang tidak bias, linier dan konsisten. Penggunaan metode ini disertai dengan asumsi yang mendasarinya, yaitu: a) Uji Normalitas, b). Uji Multikolinearitas, c) Uji Heteroskedastisitas, dan d) Uji Autokorelasi.

\section{2) Analisis Regresi Linear Berganda}

Teknik analisis yang digunakan dalam penelitian ini adalah analisis regresi linear berganda, yaitu teknik analisis digunakan untuk menguji pengaruh beberapa variabel independen terhadap suatu variabel dependen. (Mulyanto \& Wulandari, 2010).

Analisis regresi linear berganda digunakan untuk mengetahui hubungan kedua variabel independent $(\mathrm{X})$ dengan variabel dependent $(\mathrm{Y})$. Dalam penelitian ini variabel yang digunakan 
Submitted: 9 Nopember 2019; Revised: 23 Nopember 2019; Accepted: 7 Desember 2019; Published: 25 Januari 2020

yaitu: Financial Leverage (X1) dan Operating Leverage (X2) sebagai variabel bebas terhadap Rentabilitas $(Y)$ sebagai variabel terikat. Persamaan regresi linear berganda dapat dirumuskan sebagai berikut:

$$
\mathbf{Y}=\mathbf{a}+\mathbf{b}_{1} \mathbf{X}_{1}+
$$

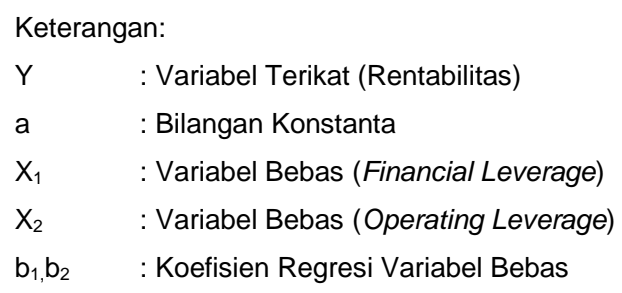

\section{3) Pengujian Hipotesis}

\section{a) Uji Parsial (Uji-t)}

Uji t digunakan untuk melihat mengetahui pengaruh secara parsial atau masing-masing) variabel independen Financial Leverage (X1) dan Operating Leverage (X2) terhadap variabel dependen Rentabilitas (Y).

\section{b) Uji Simultan (Uji-F)}

Uji F digunakan untuk melihat pengaruh secara simultan atau bersama-sama variabel independen Financial Leverage (X1) dan Operating Leverage (X2) terhadap variabel dependen Rentabilitas Perusahaan ( $Y$ ).

\section{4) Koefisien Determinasi}

Analisis koefisien determinasi adalah analisis yang digunakan untuk mengukur seberapa jauh kemampuan model dalam menerangkan variasi variabel dependen. Nilai koefisien determinasi adalah antara nol sampai dengan satu $(0<R 2<1)$. Apabila nilai $R^{2}$ mendekati Nol maka variabel independen secara keseluruhan tidak dapat menerangkan variasi variabel dependen. Sebaliknya jika besar nilai $R^{2}$ mendekati 1 (Satu) maka semakin baik karena persentase sumbangan pengaruh yang diberikan variabel independenterhadap variabel dependen adalah sempurna atau variasi variabel independen mampu menjelaskan $100 \%$ variasi variabel dependen.

\section{Hasil dan Pembahasan}

A. Uji Asumsi Klasik

1). Uji Normalitas

Uji Normalitas adalah uji yang digunakan untuk memastikan bahwa data yang digunakan berasal dari data yang berdistribusi normal. 
Tabel 2. Hasil Uji Normalitas

One-Sample Kolmogorov-Smirnov Test

\begin{tabular}{ccc}
\hline & & Unstandardized Residual \\
\hline \multirow{2}{*}{ Normal Parametersa,b } & \multicolumn{1}{c}{ Mean } & 17 \\
\cline { 2 - 3 } & Std. Deviation & ,0000000 \\
\hline \multirow{2}{*}{ Most Extreme Differences } & Absolute & 0,6565405 \\
\cline { 2 - 3 } & Positive &, 142 \\
\cline { 2 - 3 } & Negative &, 142 \\
\hline Test Statistic & \\
\hline Asymp. Sig. (2-tailed) &, 085 \\
\hline Sumber: Data diolah, 2019 & \\
\hline
\end{tabular}

Berdasarkan Uji Normalitas diatas dengan uji statistik One-Sample Kolmogorov Smirnov, menghasilkan nilai Asymp. Sig. (2-tailed) sebesar 0,200. Karena nilai signifikansi lebih besar dari taraf uji penelitian (Sig $>0,05$ ) yaitu 0,200 >0,05, Maka dapat disimpulkan bahwa data berdistribusi normal.

\section{2). Uji Multikolinearitas}

Model regresi yang baik adalah yang tidak terjadi multikolinearitas.

Tabel 3. Hasil Uji Multikolinearitas

\section{Coefficients $^{\mathbf{a}}$}

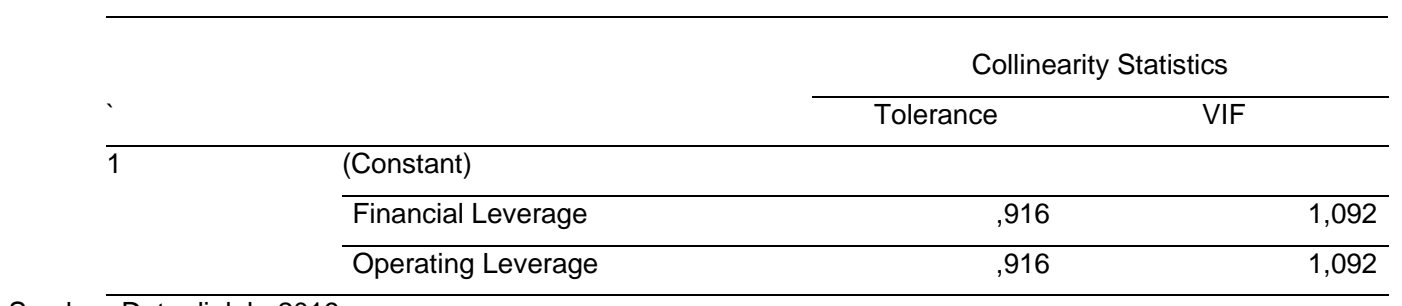

Sumber: Data diolah, 2019

Berdasarkan hasil uji multikolinearitas diatas menunjukan bahwa kedua variabel bebas tidak terjadi multikolinearitas karena VIF $<10$ dan tolerance $>0,10$. Nilai tolerance pada variabel bebas yaitu 0,916 $>0,10$ dan VIF pada variabel bebas yaitu 1,092 $<10$. Maka dapat disimpulkan bahwa model regresi tidak terjadi multikolinearitas. 
Submitted: 9 Nopember 2019; Revised: 23 Nopember 2019; Accepted: 7 Desember 2019; Published: 25 Januari 2020

\section{3). Uji Heteroskedastisitas}

Uji heteroskedastisitas digunakan untuk menguji terjadinya perbedaan variance residual suatu periode pengamatan ke periode pengamatan yang lain. Model persamaan regresi yang baik adalah yang tidak memiliki heteroskedastisitas. Untuk menguji heteroskedastisitas penelitian ini menggunakan uji glejser.

Tabel 4. Hasil Uji Heteroskedastisitas

\section{Coefficient $^{\mathrm{a}}$}

\begin{tabular}{llr}
\multicolumn{2}{c}{ Model } & Sig. \\
\hline 1 & (Constant) &, 016 \\
\cline { 2 - 3 } & Financial Leverage &, 856 \\
\cline { 2 - 3 } & Operating Leverage &, 306 \\
\hline
\end{tabular}

a. Dependent Variable: Res2

Sumber: Output SPSS 23.0; Coefficients ${ }^{a}$

Dari tabel diatas terlihat bahwa variabel Financial Leverage mempunyai signifikan $0,856>0,05$ dan signifikan variabel Operating Leverage $0,306>0,05$. Maka dapat disimpulkan sig $>0,05$ artinya model regresi telah memenuhi uji asumsi klasik yaitu tidak terjadi heteroskedastisitas.

\section{4). Uji Autokorelasi}

Menguji autokorelasi bertujuan untuk mengetahui ada atau tidaknya korelasi antara variabel pengganggu pada periode tertentu dengan variabel sebelumnya. Model regresi yang baik adalah yang tidak terjadi autokorelasi.

Untuk mengetahui ada atau tidaknya autokorelasi dilihat dari nilai Durbin Watson, dengan kriteria angka DW diantara -2 dan +2 artinya tidak terdapat autokorelasi.

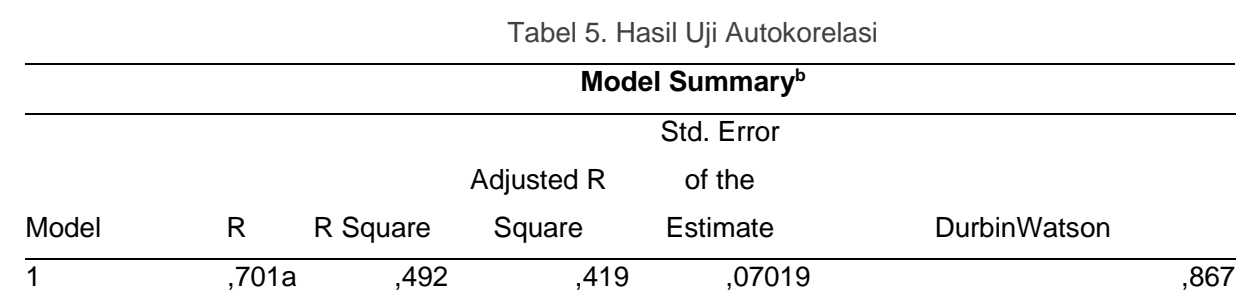

Sumber: Data diolah, 2019

Berdasarkan Hasil Uji Autokorelasi dapat diketahui nilai Durbin-Watson (d) sebesar 0,867 , kemudian dari kriteria yang telah ditentukan, maka tidak terjadi Autokorelasi, yakni $-2 \leq$ $0,867 \leq 2$, sehingga dapat disimpulkan pada model penelitian ini tidak terjadi autokorelasi.

\section{B. Analisis Regresi Linear Berganda}

Regresi Linear berganda merupakan analisis yang menggambarkan hubungan antara dua atau lebih variabel bebas dengan satu variabel terikat. Pada penelitian ini regresi linear berganda digunakan untuk mengetahui besarnya pengaruh antara variabel independen 
terhadap variabel dependen dan juga digunakan untuk melihat apakah terdapat hubungan antara Financial Leverage (X1) dan Operating Leverage (X2) terhadap Rentabilitas (Y)

Berdasarkan hasil perhitungan analisis regresi linear berganda dapat diperoleh persamaan model regresi linear sebagai berikut:

$$
\mathrm{ROE}=0,187+0,006 \mathrm{X}_{1}+0,053 \mathrm{X}_{2}
$$

Berdasarkan persamaan regresi diatas dapat dijelaskan bahwa:

1. Nilai Konstanta sebesar 0,187 menunjukan pengaruh positif pada variabel bebas yaitu Financial Leverage dan Operating Leverage.

Jika Financial Leverage $\left(\mathrm{X}_{1}\right)$ dan Operating Leverage $\left(\mathrm{X}_{2}\right)$ sama dengan nol, maka variabel terikat Rentabilitas $(Y)$ akan sebesar 0,187 satuan

2. Financial Leverage $\left(X_{1}\right)$ mempunyai koefisien regresi dengan arah positif sebesar 0,006satuan terhadap Rentabilitas (Y). Artinya jika Financial Leverage meningkat satu satuan, maka Rentabilitas akan mengalami peningkatan sebesar 0,006satuan. Koefisien yang bernilai positif artinya Financial Leverage dan Rentabilitas adalah hubungan positif.

3. Operating Leverage merupakan koefisien regresi dengan arah positif sebesar 0,053 satuan. Hal ini berarti bahwa kenaikan satu satuan pada Operating Leverage, maka Rentabilitas akan mengalami peningkatan sebesar 0,053 satuan. Koefisien yang bernilai positif artinya Operating Leverage dan Rentabilitas adalah hubungan positif.

\section{Pengujian Hipotesis}

1). Uji Parsial (Uji-t)

Uji Parsial digunakan untuk melihat pengaruh secara parsial variabel independen Financial Leverage dan Operating Leverage terhadap variabel dependen Rentabilitas. Kriteria dalam pengujian secara parsial adalah dengan ketentuan nilai signifikansi uji $\mathrm{t} \leq 0,05$ dan jika thitung > t-tabel maka artinya terdapat pengaruh secara parsial antara variabel independen terhadap variabel dependen

Tabel 6. Hasil Uji Parsial

\section{Coefficient $^{\mathrm{a}}$}

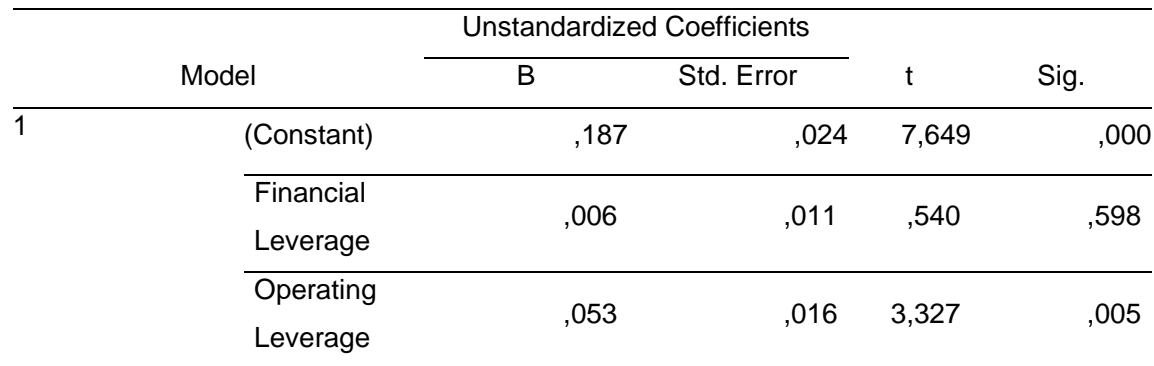

Sumber: Data diolah, 2019

Berdasarkan Hasil Uji Parsial diatas diperoleh hasil sebagai berikut: 1). Hasil Uji ParsialFinancial Leveragediperoleh nilai signifikansi sebesar 0,540>0,05 dan hasil uji t-hitung dibawah t-tabel $(0,540<2,145)$ sehingga apat ditarik kesimpulan bahwa secara parsial Financial Leverage $\left(\mathrm{X}_{1}\right)$ tidak berpengaruh signifikan terhadap Rentabilitas, 2). Hasil Uji Parsial Operating 
Submitted: 9 Nopember 2019; Revised: 23 Nopember 2019; Accepted: 7 Desember 2019; Published: 25 Januari 2020

Leverage diperoleh nilai signifikansi sebesar $0,005<0,05$ dan hasil t-hitung lebih besar dari ttabel $(3,327>2.145)$ sehingga dapat ditarik kesimpulan bahwa Operating Leverage secara parsial berpengaruh signifikan terhadap Rentabilitas.

\section{2). Uji Simultan (Uji-F)}

Uji F digunakan untuk melihat pengaruh secara simultan pada Financial Leverage dan Operating Leverage terhadap Rentabilitas. Kriteria dalam pengujian secara simultan adalah dengan membandingkan tingkat signifikansi dari $(\alpha=0,05)$ dengan ketentuan apabila nilai signifikansi $\leq 0,05$ dan jika diperoleh hasil t-hitung $>$ t-tabel artinya secara simultan terdapat pengaruh signifikan.

Tabel 7. Hasil Uji Simultan

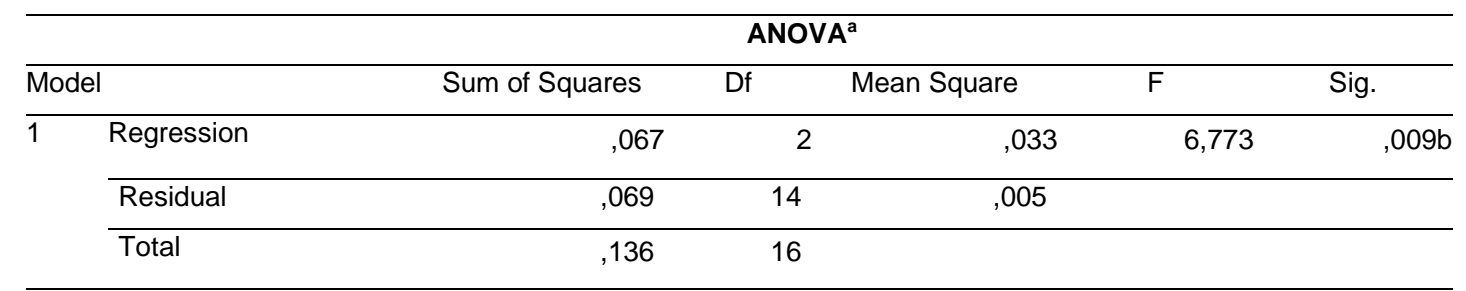

Sumber: Data diolah, 2019

Berdasarkan tabel diatas diperoleh F-hitung sebesar 6,773 sedangkan F-tabel sebesar 3,68 berarti 6,773>3,68 dengan signifikansi 0,009<0,05 maka dapat dikatakan bahwa variabel Financial Leverage dan Operating Leverage secara bersama-sama berpengaruh signifikan positif terhadap Rentabilitas.

\section{Koefisien Determinasi}

Analisis koefisien determinasi adalah analisis yang digunakan untuk mengukur seberapa besar kontribusi variabel bebas terhadap variabel terikat. Apabila nilai R2 mendekati Nol maka variabel independen secara keseluruhan tidak dapat menerangkan variasi variabel dependen. Sebaliknya jika besar nilai R2 mendekati 1 (Satu) maka semakin baik karena persentase sumbangan pengaruh yang diberikan variabel independen terhadap variabel dependen adalah sempurna.

Tabel 8. Hasil Uji Autokorelasi

Model Summaryb

\begin{tabular}{|c|c|c|c|c|}
\hline Model & $\mathrm{R}$ & R Square & Adjusted R Square & $\begin{array}{c}\text { Std. Error } \\
\text { of the Estimate }\end{array}$ \\
\hline 1 & ,701a & ,492 & 419 & 07019, \\
\hline
\end{tabular}

Sumber: Data diolah, 2019

Berdasarkan tabel diatas dapat dilihat koefisien determinasi $\left(R^{2}\right)$ sebesar 0,492 artinya bahwa sebesar 49,2\% menunjukan bahwa presentase sumbangan pengaruh variabel independen Financial Leverage dan Operating Leverage terhadap variabel terikat Rentabilitas sebesar $49,2 \%$. Sedangkan $50,8 \%$ dipengaruhi oleh faktor lain yang tidak dibahas pada penelitian ini. 


\section{E. Pembahasan}

1). Pengaruh Financial Leverage $\left(X_{1}\right)$ terhadap Rentabilitas (Y) PT. Kalbe Farma, Tbk

Berdasarkan hasil penelitian yang telah dilakukan, melalui uji t (uji parsial) dapat diketahui bahwa tidak terdapat pengaruh secara parsial pada Financial Leverage (X1) terhadap Rentabilitas (Y). Hasil penelitian ini didukung hasil penelitian Yuni Anisa (2017), yaitu Financial Leverage tidak memiliki pengaruh terhadap Rentabilitas (ROE). Artinya Kebijakan Financial Leverage tidak selalu meningkatkan Rentabilitas Perusahaan. Hal ini terjadi dikarenakan PT. Kalbe Farma, Tbk cenderung lebih banyak menggunakan ekuitas dibandingkan dengan hutang jangka panjangnya. Melalui hasil uji-t dapat dikatakan bahwa perubahan naik atau turunnya Financial Leverage tidak mempengaruhi besarnya Rentabilitas pada PT. Kalbe Farma, Tbk.

\section{2). Pengaruh Operating Leverage $\left(\mathrm{X}_{2}\right)$ terhadap Rentabilitas ( $\mathrm{Y}$ ) PT Kalbe Farma, Tbk}

Berdasarkan hasil uji t (uji parsial) dapat diketahui bahwa variabel Operating Leverage berpengaruh signifikan terhadap Rentabilitas. Hasil penelitian ini didukung hasil penelitian (Wahyu, Dewi, \& Cipta, 2016) yaitu Operating Leverage berpengaruh terhadap Rentabilitas $(\mathrm{ROE})$. Artinya Penggunaan Operating Leverage memiliki peran dalam upaya meningkatan Rentabilitas (ROE). Perusahaan yang menggunakan biaya tetap yang tinggi dikatakan bahwa perusahaan tersebut menggunakan Operating Leverage yang tinggi, perusahaan yang menggunakan Operating Leverage yang tinggi, tingkat penjualan yang dihasilkan juga harus meningkat. Hal ini terjadi dikarenakan PT. Kalbe Farma, Tbk mampu menggunakan biaya tetap untuk memperbesar pengaruh dari perubahan volume penjualan terhadap Laba. Maka dapat disimpulkan bahwa variabel Operating Leverage akan mempengaruhi besarnya Rentabilitas pada PT. Kalbe Farma, Tbk.

3). Pengaruh Financial Leverage $\left(\mathrm{X}_{1}\right)$ dan Operating Leverage $\left(\mathrm{X}_{2}\right)$ secara simultan terhadap Rentabilitas (Y) PT. Kalbe Farma, Tbk

Pada penelitian ini Rentabilitas yang digunakan adalah Return On Equity. Rasio ini menggambarkan efisiensi perusahaan dalam menghasilkan laba dengan modal sendiri yang dimiliki perusahaan. Hasil perhitungan Return On Equity sangat dipengaruhi oleh laba yang dihasilkan perusahaan. Sedangkan Leverage menunjukan kemampuan perusahaan dalam mengelola modal dalam bentuk utang untuk menghasilkan Laba yang maksimal. Kemudian dari hasil penelitian melalui uji simultan dapat diketahui bahwa secara bersama-sama variabel bebas Financial Leverage (X1) dan Operating Leverage (X2) mempunyai berpengaruh terhadap variabel terikat Rentabilitas $(\mathrm{Y})$.

\section{Kesimpulan}

Berdasarkan hasil penelitian dan pembahasan pada bab sebelumnya, maka dapat diambil kesimpulan yaitu sebagai berikut: 1). Berdasarkan hasil pengujian secara parsial, diketahui bahwa variabel bebas Financial Leverage secara parsial tidak berpengaruh signifikan terhadap Rentabilitas PT. Kalbe Farma, Tbk. Kondisi seperti ini dapat terjadi ketika kebijakan Copyright $\odot 2020$ Jurnal JKI 20 (1): 29 - 42 (Januari 2020) 
Submitted: 9 Nopember 2019; Revised: 23 Nopember 2019; Accepted: 7 Desember 2019; Published: 25 Januari 2020

hutang perusahaan tidak menunjukkan peningkatan kinerja perusahaan. 2). Berdasarkan hasil uji secara parsial, diketahui bahwa Operating Leverage secara parsial berpengaruh signifikan terhadap Rentabilitas PT. Kalbe Farma, Tbk. Hal ini terbukti pada peningkatan Penjualan dan EBIT yang dicapai PT. Kalbe Farma, Tbk. 3). Hasil uji secara simultan (Uji-F) diketahui bahwa seluruh variabel independen Financial Leverage (X1) dan Operating Leverage (X2) secara bersama-sama berpengaruh signifikan positif terhadap variabel dependen Rentabilitas ( $Y$ ). Berdasarkan hasil penelitian, maka implikasi manajerial yang dapat dikemukakan adalah sebagai berikut: a). Pada hasil penelitian ini kebijakan Financial Leverage tidak bisa dijadikan faktor utama dalam meningkatkan Return On Equity, kondisi seperti ini dapat terjadi ketika kebijakan hutang perusahaan tidak dapat mencetak profit yang lebih tinggi. b). Pada hasil penelitian Operating Leverage yang mempengaruhi Rentabilitas (ROE). Manajemen Perusahaan perlu untuk mempertahankan atau bahkan meningkatkan pengelolaan Operating Leverage karena dari pengelolaan tersebut. Hal ini terbukti pada pencapaian tingkat Penjualan dan EBIT yang mengalami peningkatan. c). Berdasarkan hasil perhitungan Rentabilitas mengalami penurunan sedangkan modal dan laba PT. Kalbe Farma, Tbk terus mengalami peningkatan. Maka pihak manajemen perusahaan perlu untuk mencetak profit yang lebih besar dengan modal yang dimiliki.

\section{Daftar Pustaka}

Ashari, M. H., \& sampurno, R. D. (2017). Pengaruh leverage keuangan terhadap profitabilitas pada perusahaan pariwisata yang terdaftar di bursa efek indonesia periode 2011-2015, 6(2002), 1-12.

Lestari, Y. A., \& Nuzula, N. F. (2017). Analisis pengaruh financial leverage dan operating leverage terhadap profitabilitas perusahaan (studi pada perusahaan sektor keuangan yang terdaftar di bursa efek indonesia Periode 2012-2015), 46(1), 1-10.

Mulyanto, H., \& Wulandari, A. (2010). Penelitian Metode dan Analisis. Semarang: CV. Agung.

Patel, \& Bodiwala, N. (2014). Impact of Leverage on Profitability: A Study of Sabar Dairy, 7637(3), 1-6.

Rodoni, A., \& Ali, H. (2014). Manajemen Keuangan Modern. Jakarta: Mitra Wacana Media.

Sujarweni, V. W. (2015). Metodologi Penelitian Bisnis dan Ekonomi. Yogyakarta: Pustaka Baru Press.

Wahyu, K., Dewi, K., \& Cipta, W. (2016). Pengaruh Operating Leverage dan Debt to Equity Ratio Terhadap Profitabilitas Pada Perusahaan Sektor Industri Logam dan Sejenisnya, $4(1), 1-9$.

Wardiyah, M. L. (2017). Analisis Laporan Keuangan. Bandung: CV Pustaka Setia. 